\title{
ARTICLES:
}

\section{The Development of Yasukawa Electric Co. and its Entrepreneurial Activities}

By Shin Hasegawa

Shizuoka University

\section{Aim of the Paper}

Yasukawa Denki Seisakusho (Yasukawa Electric Manufacturing Co.), founded in 1915, was part of the diversification strategy adopted by the Yasukawa family, whose business originally had been concentrated in coal mining. Although Yasukawa Denki was hardly ever in a position to make a profit during its first seventeen years, thereafter it grew quickly as a specialist manufacturer of electric motors. The growth came from taking advantage of a rationalization of its product range during what is known in Japan as the Showa Kyokoki (a period of financial panic in 1929-32, the Showa Crisis). In the 1930s it became an important company whose annual turnover equaled that of the Meidensha Co., ranked fifth among the major heavy electrical machinery makers in Japan, namely Shibaura Seisakusho (Shibaura Manufacturing Co.), Hitachi Seisakusho (Hitachi Manufacturing Co.), Mitsubishi Denki (Mitsubishi Electric Manufacturing Co.) and Fuji Denki Seizo (Fuji Electric Manufacturing Co.). The aim of this paper is to examine and explain the conditions that facilitated the rapid growth of the company during the 1930s from the viewpoint of entrepreneurial activities on market exploitation, product development and capital investment that contributed to this growth. ${ }^{1}$

Establishing this sort of aim also implies an intention to clarify the characteristic features of the diversification of the business undertaken by the Yasukawas, a Northern Kyushu family possessed of a considerable fortune. Having started in coal mining, the Yasukawas later diversified into manufacturing, such as cotton-spinning and steelmaking, undertakings characterized by Hidemasa Morikawa as industryoriented. Morikawa also counts the Yasukawa business as one of the so-called "Chiho (regional) Zaibatsu." Moreover, by analyzing the decision-making process of Daigoro Yasukawa, the founder of the 
Yasukawa Electric Company, through documentary sources such as his diaries, Morikawa has also been able to identify the Yasukawas' mode of strategic decision-making, which typically involved only the family members, and mark the unusually high ratio of salaried managers. He saw this as rare in a mere provincial family business, and cites these elements as features peculiar to the Yasukawa enterprise. ${ }^{2}$

However, his analysis does not adequately explain how the diversification of the family business and the subsequent expansion and growth of its subsidiaries and affiliates might possibly have influenced or even altered the process of decision-making involving only the family members. Similarly, it fails to explain the apparent contradiction between the family-based decision-making process and the high ratio of salaried managers. The intention here, therefore, is that during the course of tracing the entrepreneurial activities of the Yasukawa Electric Company, an attempt will be made to bring to light the actual process of decision-making practiced by the Yasukawa family in managing the diversified business it owned. In addition, a description of changes during a particular period will also be provided. ${ }^{3}$

\section{From the Beginning to the First World War}

A study of the events surrounding the establishment of Yasukawa Electric Company makes two things stand out clearly. First, there is the contrast between the positive entrepreneurial enthusiasm for manufacturing held by Keiichiro Yasukawa, founder of the Yasukawa family business, in opposition to the lack of conscious effort by Daigoro, Keiichiro's fifth son, to translate his own technological knowledge into entrepreneurial activities. Second, there is the very close cooperation among the family members centering on Kenjiro Matsumoto and Seizaburo Yasukawa, Keiichiro's second and third sons.

In selecting a suitable site for building the Yasukawa Denki factory, the three brothers, Seizaburo, Kenjiro and Daigoro, inspected several places in December 1914. They finally decided on a site, now called Kurosaki, in Kita-Kyushu-Shi. In April the following year they established an office there and began preparing the site for factory construction. The membership of the Yasukawa Electric Company, a goshi kaisha (limited partnership), included Seizaburo Yasukawa, Daigoro Yasukawa and Kenjiro Matsumoto, all with unlimited liability and $¥ 50,000$ capital each, plus Keiichiro Yasukawa, with capital of 
$¥ 100,000$ but limited liability. The company was represented by Daigoro. In reality the total capital of $¥ 250,000$ came from Keiichiro, and although he provided all the required capital he took no active part in running the business. Daigoro, only thirty, thus had the responsibility of running it with the help of his two elder brothers, Seizaburo and Kenjiro. Judging from the entries in Keiichiro's diary of the time, it is apparent that his entrepreneurial interest was mainly focused on iron manufacturing, since there is very little mention of Yasukawa Electric Company during 1915. It is possible that Keiichiro at that time had no real appreciation for the uncertain future that lay ahead for the heavy electrical machinery business. It is not until July, 1921 that we detect his awareness of the unforeseen difficulties that the heavy electrical machinery business was facing.

The main problem that Yasukawa Electric Company had to grapple with in the beginning was the lack of accumulated experience in design and manufacturing technology. To resolve this, Daigoro invited Yasujiro Sakai of the Takada Trading Company, a man known to have first-class technical capabilities in designing heavy electrical appliances. Daigoro had met him before he went to the U.S. and appointed him Chief Engineer, but prior to the appointment Keiichiro had to first negotiate Sakai's entry into Yasukawa Electric Company with Fusanosuke Kuhara of the Hitachi Manufacturing Company, who had wanted to recruit Sakai himself.

Although there were delays in obtaining some of the steel building materials from overseas due to the First World War, construction of the factory progressed without undue hitches, with Sakai overseeing the installation of plant equipment. Other men, with some years' experience with Shibaura Manufacturing Company and other firms, were recruited to work under Sakai in the design area. In the second half of 1916 they worked on product design for items intended both for use in the substations of the Company and to meet orders from Yasukawa Group firms such as Meiji Mining Company and Meiji Cotton Spinning Company. On completing the factory in December 1916, manufacturing activities commenced, with sales and marketing starting in January 1917.

Production at Yasukawa Electric Company expanded, with electric motors and transformers taking the main share. During 1919, 72 of the total 104 items being produced were for general sales outside the Yasukawa Group of companies. They went to electricity-generating concerns such as Kyushu Hydro-Electric Generating Co., and mining operations such as Kaijima Mining and Miike Mining. Sales expansion 
focused on Kyushu as the main market, but marketing policy at this time reflected clearly that the company and especially its manufacturing technology were still in a trial period.

There is an anecdote that relates that Yasukawa Electric's marketing man went around to his customers asking them to order as many different kinds of electrical products as possible even if the volume for each was small. This was to enable Yasukawa to expand its product range, but it was viewed as a rather strange strategy. The balance sheet often showed losses, and when Yasukawa Electric Company merged with Yasukawa Electric Manufacturing Company Ltd. in March 1920, it carried over losses of over $¥ 90,000$. Business operations had in fact coincided with very favorable internal market conditions stimulated by the First World War, whereby the demand for electrical goods increased but could not be met by decreasing of imports. Despite this advantage, the company failed to capitalize on the opportunity because its manufacturing and marketing systems were not sufficiently developed and coordinated to take full advantage of favorable market conditions.

As the scope of operations expanded, the Yasukawa Electric Manufacturing Company Ltd., with capital of $¥ 1,250,000$, was established in December 1919. In March the following year it absorbed the existing limited partnership, enabling it to start fresh with capital of $¥ 1,500,000$. The top management of the new company included Seizaburo as President, Daigoro as Executive Director and Kenjiro in the post of Auditor. As the main preoccupation of both Seizaburo and Kenjiro was the coal business, and since Chief Engineer Sakai had resigned in October 1919 amid labor-management problems, Daigoro was in fact solely responsible for management of the electrical business while having to cope with the overall responsibility for the technical side of the business.

\section{Establishment of Manufacturing \& Sales Organizations - The Tamari Era}

\section{(1) Establishing the Sales Network}

At this time Seizaburo and Kenjiro were still concerned over Daigoro's lack of managerial experience. They decided to recruit Shichiji Tamari, then in the Osaka Branch of Mitsui Bussan (Mitsui Trading Co.) as a dealer in raw cotton. They appointed him General Manager in June 1920. In terms of organizational hierarchy, the General Manager was directly subordinate to the Executive Director 
and in charge of both the manufacturing and sales operations. However, Tamari concentrated more of his efforts on sales while looking after general affairs and the accounts.

The June 1920-December 1926 period came to be termed the Tamari Era, and during this time two local offices were established, one each in Osaka (November 1920) and Tokyo (June 1921), initiating the development of a sales organization. The Osaka unit shared facilities with the Osaka Office of Meiji Spinning Co., while the Tokyo unit was established on the premises of the Tokyo Branch Office of Yasukawa Matsumoto Shoten (Yasukawa Matsumoto Co.), the sales organization of Meiji Mining Co. It was managed by Yasukawa Matsumoto Shoten's Branch Manager, Gen'ichiro Matsumoto, who also acted as head of the Tokyo Office for the company. Arrangements were made for Yasukawa Matsumoto Shoten to handle invoicing and the receipt of payments for merchandise, plus bookkeeping, while the final accounts were settled between its head office in Wakamatsu and the head office of Yasukawa Electric Manufacturing Co. The cost of maintaining the Tokyo Office was also defrayed by Yasukawa Matsumoto Shoten. Thus the Yasukawa Group played an important role in the curtailment of indirect sales costs and the financing of working funds for the Yasukawa Electric Manufacturing Co. during this crucial initial stage.

From about 1923 and 1924, the development of a market by the electricity-generating industry entered its main phase, and orders for large pieces of equipment were placed. Using externally made water turbines, Yasukawa Denki (Yasukawa Electric Manufacturing Co. from now on) manufactured water-turbine generator sets, and starting with the sale of a $3,750 \mathrm{KVA}$ set to Nihon Suiden (Nihon Water Power Electric Co.) in 1925, began to attract customers, including Nihon Chisso Hiryo (Nihon Nitrogenous Fertilizer Co.). The transformers that Yasukawa Denki had been manufacturing until then were pole-mounted, but after 1923 large 6,000KVA transformers were supplied to Nihon Chisso and other firms. But according to Godai Sagara, sales chief under Tamari, these were only competitive when a large discount was given, making it necessary to sell them below cost. Therefore, although the market for their products increased, it did not result in improved business performance.

On the other hand, Tamari vigilantly monitored not only purchases of raw materials but also the efficiency of clerical work to reduce costs. In this initial period, when the company lacked sufficient personnel with business experience, Tamari's role in consolidating the 
foundations of the firm - in sales, purchasing and clerical management - was undoubtedly crucial. However, Tamari lacked knowledge about production, and had an inadequate grasp of the importance of product development.

(2) Improvements in Design and Manufacturing Technology

The basic product design work was generally done by a team headed by Sakai, the chief engineer. The subsequent rapid improvements in heavy electric motors made it necessary for them to design a whole range of new products. However, at that time the design department lacked a clear direction for new product development. Essentially the design staff were at the stage where they were consolidating basic design technology only through the experience of designing new products based on orders that they had never dealt with before. They also resorted to copying imported equipment when faced with designs requiring a higher level of technology than they possessed. This latter approach was shown when they were asked to supply a $1,000 \mathrm{HP}$ induction motor in 1925 . They were able to design one from a sketch of a 2,000HP motor made by General Electric that had just been supplied to Kyushu Seiko (Kyushu Steel Mfg. Co.).

On the manufacturing side, an improvement in the iron-core processing technique for motors was achieved by a German engineer. $\mathrm{He}$ had been transferred to them from the Oana Seisakusho (Oana Mfg. Co.), bringing about an improvement in performance, as well as a reduction in both size and weight, of the rotating machine. This development paved the way for future standardization. This German engineer also contributed greatly to the consolidation of the technological foundation of Yasukawa Denki by introducing many new techniques, such as an insulation technique using baked-on mica. The Company also recruited other engineers/technologists from the Shibaura Mfg. Co. to help introduce insulation techniques. Although Daigoro appears to have largely left the management of the manufacturing side of the company to the works manager, he did show his concern for building up technical personnel resources by interviewing personally not only the German engineer but also the other technologists when they were being hired. He also terminated the practice of using those who were really electrical equipment designers for designing machines. He did this by hiring specialists in machine design, thereby expanding and improving the effectiveness of the Design Department. In this way Daigoro put a lot of effort into creating an environment in which the conditions required for technological 
progress could be met, even though he lacked a clear overall business policy. In January 1926 Taiichi Yasukawa entered the company with the intention of devoting his efforts to the creation of standard designs for machine parts for the motors. ${ }^{4}$

During the 'Tamari Era' (1920-26), however, the working relationship between the Manufacturing and Sales Departments was not necessarily harmonious. For example, when Tamari heard that there was a discrepancy between the specification for insulation and the actual technique employed for applying the insulation, he demanded that the specification be followed by the latter. Those responsible for design responded that, given the existing manufacturing facility, the specification could not be met and therefore the modification was justified. The design team appealed directly to Daigoro to adjudicate in their favor. Yasukawa Denki simply did not have someone who could lead the Manufacturing Department with the same imagination for product development as Daigoro.

The Kanto Daishinsai (The Great Kanto Earthquake) struck in September 1923. The manufacturing and sales organizations of Yasukawa Denki were just beginning to take shape, and its initiative in finding a market for their products, especially in the Kanto Region, had only just started. The earthquake demolished the Shibaura Plant and other factories in Tokyo. The company was unable to take advantage of the opportunities created by the subsequent rush in orders, which went to firms with plants in Kansai and other unaffected regions. As a result, sales remained low in 1925 and 1926, and Tamari resigned in December 1926.

\section{The Era of General Manager S. Nunome - A Period of Positive Policies -}

(1) Progress in the Marketplace

Sanshiro Nunome entered the company as its new General Manager in May 1927, and began to take charge of Manufacturing and Sales. ${ }^{5}$ The positive policy decisions taken under his management soon began to bear fruit in increased orders. According to Tadao Kimi, who was assigned to the Osaka Office in 1929, the number of Marketing and Sales staffers at the Osaka Office was about three, including Office Manager Sagara. Their main customers were Nippon Chisso, Osaka Yogyo (Osaka Cement Co.), Ajikawa Tekkosho (Ajikawa Manufacturing Co.), Dainihon Boseki (Dainihon Cotton Spinning Co.), Kurashiki Boseki (Kurashiki Cotton Spinning Co.), Toyo 
Boseki (Toyo Cotton Spinning Co.), and others. The marketing staff had been finding it increasingly difficult to cope with expanding sales, and since 1927 had been using distributors to win new customers. The first distributor was a trader dealing in various products for construction, machinery, etc., and this company took on the task of finding a new market segment in the Kobe area. An early success was achieved in 1928 with an order for four 5,000KVA transformers from Kobe-Shi Denki Kyoku (Kobe City Electric Division), on which much of the sales drive had been focused. According to the recollections of one of the Osaka Office staff of the time, the main emphasis of the marketing strategy of the Osaka Office was on the sale of transformers and their accessories. This assisted the increase in total sales rather more than sales of motors, which brought in a relatively small return. Thus, while it put enormous effort into getting orders from Toho Denryoku (Toho Electric Power Co.) and Daido Denryoku (Daido Electric Power Co.), it took two months to supply small motors of one or two horsepower to customers.

The company tried to extend its market at this time with a new product: motors for ring spinning machines in the cotton spinning industry. Daigoro had heard a report in February 1928 from one of its staff who had been to the Nagoya and Osaka areas to promote sales of the company's commutator motors. He also heard, in June of the same year, a report on motors for ring spinning machines at Toyo Boseki from an employee who had been sent to Osaka to have a look at them. Daigoro himself took a role in the sales drive, making a point of visiting Fuji Boseki on a business trip to Tokyo. Many of his diary entries for 1928 and 1929 related to motors for spinning machines. When he visited Tokyo in July 1928, he called on Fuji Denki (Fuji Electric Co.) on the 23rd to conclude a marketing agreement on motors for their spinning machines. On the 25th he held another meeting with Fuji Denki, and Toyo Denki Seizo (Toyo Electric Mfg. Co.) was also involved. A decision was reached to effect an agreement that same day. On October 8 the tripartite meeting was named Hatsuka-kai, and a decision was almost reached on the articles of the agreement. However, the following year, upon hearing a dissident voice within his own company concerning the contents of that agreement, Daigoro left the matter in the hands of Nunome. The general manager thereafter took charge of matters relating to the three-company Hatsuka-kai and his areas of responsibility spread outward.

While there were some initiatives for cooperation in a sector of the 
industry, the general trend in the heavy electric motor market was toward increasing competition. The Hitachi Seisakusho (Hitachi Manufacturing Co.) adopted an aggressive marketing strategy in 1929. This began to threaten Yasukawa Denki's home market, Kyushu. The sales staff reported that Hitachi had been undercutting prices, thereby gaining market share in the iron and steel industry and other industries in northern Kyushu, and this was causing them some anxiety. The competitive ability of Yasukawa Denki was also poor in the market for large-capacity generators and transformers. For example, there was the case of an inquiry from Showa Hiryo (Showa Fertilizer Co.) for a transformer with an estimated price of more than $¥ 200,000$ in November 1928. Daigoro visited Showa Hiryo on his business trip to Tokyo in February 1929 and inspected the list of estimates submitted by the bidding companies. To his dismay he discovered that the Yasukawa Denki estimate was one of the highest and had no chance of being considered. With an increase in the number of orders, the company began to make a small profit in 1929, and the policy of taking the initiative in the market seemed to be paying off. However, in a climate of increasing price competition, this did not go so far as to result in any radical change in the company management.

\section{(2) Vitalizing Product Development}

In the heavy electrical machinery market, where the general trend was toward large-capacity machines, Yasukawa's manufacturing technology for large-capacity transformers and generators lagged behind. Furthermore, the production of pole transformers - for which anticipatory production had once been very keen - now slowed considerably. Competing directly with these products and in the electric motors field were a series of new products coming on the market, including the commutator motors mentioned earlier. The super-synchronous motor and the KBQ electric motor were typical of these new developments. Production of super-synchronous motors was seemingly attributed to a chance suggestion from a customer. In the autumn of 1926, the Chief Electrical Engineer of Asano Cement had intimated to Yasukawa Denki that a new, special electric motor had recently been imported. He added that he foresaw increased demand for it from the cement industry, and recommended that Yasukawa Denki start making it anticipating this demand. Yasukawa Denki sent Masayuki Ono, in charge of electrical design, to make sketches of the imported super-synchronous motor at Nihon Cement 
Co., where one of the motors was installed. This started the ball rolling, and the first chance at an order for the motor came the following year, 1927. An inquiry arrived from Osaka Yogyo (Osaka Cement Co.) for two electric motors, one with 500HP and another $250 \mathrm{HP}$, for their milling machines, and Yasukawa Denki submitted a plan of the super-synchronous motor on the off chance that it might interest them. It did. Ono took charge of designing the electrical parts, and the mechanical parts were designed by Taiichi Yasukawa, who had just entered the Company. However, within the Company there was strong opinion against accepting the order for supersynchronous motors. According to the recollections of Taiichi, he discovered from the man in charge of the Osaka Office that since the design of super-synchronous motors was known to be very difficult, it had become head office policy to respond to orders by offering the existing induction motors. Incensed by this change in attitude, in which the actual designers of the motors were not consulted, Taiichi made the Osaka Office accept the order for the super-synchronous motors on his behalf, and the order was confirmed in February 1927. From then on, orders for super-synchronous motors flooded in from cement manufacturers, and by the end of 1929 they had supplied 26 such motors to various firms.

It was in 1928 that anticipatory production of small electric motors commenced. When Taiichi entered the company in 1926, Yasukawa Denki was not producing motors on an anticipatory basis. Convinced that the company was losing out, Taiichi suggested to his superior on three occasions that the company implement such a policy even if initially it proved to be unprofitable, since this could be regarded as an outlay for advertising the product and helpful in the long term. His suggestion was rejected. Taiichi, then still new to the company, had to remain discontented with the prevailing atmosphere until he was promoted to the post of Chief Mechanical Design Engineer by Nunome. His proposal to start the anticipatory production of small motors was then put to Nunome and approved. Taiichi was of the opinion that if Yasukawa Denki was to succeed in anticipatory production, where it was behind other firms, it had to offer the market a product that differed in a significant way from other products. He suggested the use of ball races for the bearing sleeves of small electric motors. Although Nunome approved his suggestion, Nunome felt it prudent to temper it with a compromise plan, not only because he himself was then relatively new to the company, but also because Yasukawa Denki was undergoing hard times and that there was 
bound to be some opposition to the idea from the older, longer-serving members. The compromise was to apply the idea to a limited range of small motors, and ball races were used in some of the five and ten HP motors, thus realizing Taiichi's idea even if only partially. When $1 / 2 \mathrm{HP}$ motors were newly marketed, ball races were used throughout, and this practice gradually spread to all small motors.

In March 1929, a new small electric motor called the LSQ, featuring ball races as bearings, was designed. Until then standard electric motors were made in accordance with General Electric Co.'s open construction, in which the iron core was left exposed. The idea for LSP-type motors originated from Taiichi's line of thinking. This was that the small electric motors which the company was producing should have design features that bore plainly the hallmark of Yasukawa Denki so that there would be no need for anyone to seek the maker's nameplate on it. He therefore designed an enclosed drip-proof standard motor that incorporated a good appearance, an important feature for the mass market. Predictably, there was some opposition to this from within the company bemoaning that, as it was not of the open type, it wouldn't be suitable as the standard motor. Taiichi set about persuading the opposition, using such exaggerated expressions as "The LSQ is the electric motor of the New Age," and that it was the "Electric Motor of Tomorrow," eventually managing to get the idea approved.

Taiichi was acutely aware of the necessity for Yasukawa Denki, a late entrant in the market, to offer something different from other makers if it was to succeed in the small electric motor segment of the market. He recognized the importance of product differentiation as well as of price-competitiveness, and he made it his business to incorporate it into product development. Of course, Taiichi could not make these new products singlehandedly. He was helped not only by Ono, who was responsible for the design of the electrical parts, but also by other young engineers who entered the company during the same period as he did and were involved in the actual design tasks. Such developments indicated that there had been a substantial improvement in the competence of the technical personnel employed.

However, not all plans for product development went smoothly, and Yasukawa Denki encountered various obstacles. In the case of motors for electric trains, Yasukawa Denki failed to become the appointed manufacturer to the Ministry of Railways, despite having made the prototype main motor for the Ministry's electric locomotive and that Daigoro had made repeated efforts to persuade them. Also, 
as the Yasukawa Denki's product development progressed, problems occurred regarding patents involving other firms. The 30HP electric motor supplied to Kyushu Tanko Kisen (Kyushu Colliery Steamship Co.) in 1927 was the first of the totally enclosed type, and it was well received by the coal mining and other industries. In 1929, however, Hitachi issued an objection that the motor's cooling system infringed a Hitachi patent. Daigoro immediately rushed to see Namihei Odaira, president of Hitachi, on June 4 to propose a way of handling the patent problem. Hitachi's Odaira refused to accept this in an uncompromisingly severe reply received on September 17 . Consequently, Yasukawa Denki had to develop a different cooling system. This accurately reflected the sensitive and competitive situation at the time, when Yasukawa Denki and Hitachi had to be extremely wary of each other about patents as product development competition increased.

In this fiercely competitive climate, Yasukawa Denki's main priority was the development of electric motors. Taiichi's approach to new product development gradually gained the ascendancy although still encountering some opposition from within the company. This indicates that, among the technical staff of Yasukawa Denki, the ability to conceptualize was developing. However, on the marketing side, the emphasis was still on obtaining orders for transformers and related accessories and there was still no organization for distributors to handle the sale of standard electric motors. Clearly, there was a lack of coordination between manufacturing and marketing policies.

\section{(3) Lack of Management Coordination}

Nunome, who was basically a specialist in metal rolling, entered Yasukawa Denki in May 1927, and became a Director in February 1929. His involvement in the manufacturing aspect of the company was such that he would make a daily round of the shop floor. If he discovered any unsuitable materials for production, he called the buyer from the shop floor to complain. Unlike his predecessor Tamari, a marketing man, Nunome actually held both the manufacturing and marketing divisions under his control, and his activities covered a very wide area. These included improving plant equipment and facilities, opening new market opportunities and carrying out negotiations for industry-wide cooperation. Where it concerned manufacturing, Nunome's management policy was progressive, and he adopted a positive approach to the development of new products and the introduction of new technologies, such as welding techniques. 
At the same time, his marketing policy was to opt for an increase in the volume of orders, even if this at times had to be achieved at the expense of profit margins.

In 1926 Daigoro turned forty and was maturing into a good manager. The idealistic words and deeds so conspicuous in his youth at the time of the establishment of the company were now well behind him. As far as we can gather from his diary entries for 1928 and 1929, the main emphasis of his internal business activities was placed on two points: to make judgments or decisions on various matters, such as whether to accept an order, based on the reports he got from the marketing division; and the control of the monthly budget, settlement of accounts, assessment of bonuses, and procurement of funds, etc., which were related to the finances of the company. However, on the first point, there were cases where decisions on large orders, such as that placed by Naigai Boseki (Naigai Cotton Spinning Co.), were delegated to Nunome and his subordinates. This indicates that the general manager played a considerable part in making marketing decisions. Daigoro also made frequent rounds of the factory, but did not himself issue any directives or direct the manufacturing division.

Externally, he was fairly well involved in various activities and went to Tokyo and Osaka at least once a month, combining marketing activities for the company with participation in industry-related activities. He attended meetings of the committee of Nihon Denki Kyokai (Japan Electric Association), was involved in talks on the formation of cartels, and lobbied on the company's behalf to become an appointed manufacturer to the Ministry of Railways and in other areas. In Kyushu, he attended the general meetings of Meiji Boseki (Meiji Cotton Spinning Co., a limited partnership) as one partner of the company, but did not get involved in routing management matters of the other Yasukawa companies. As for his involvement in the zaikai (business world), he was appointed chairman of Yawata-shi Shokokaigisho (Yawata City Chamber of Commerce and Industry) in December 1928. He also donated some time to settling problems arising from the conflicting interests of businesses in the local area. Apart from these matters, he also taught electrical engineering once a week at Meiji Senmongakko (Meiji Technical College), which Keiichiro had established. Of all the activities he undertook, the development of marketing interested him most.

During 1928 Yasukawa Denki continued to show losses. Consequently, Daigoro was greatly preoccupied with the need to improve marketing. He became convinced that marketing revitalization was 
absolutely essential for the improvement of the company management. The entry for February 3, 1928 shows that he was deeply concerned that the level of orders received had not reached projections. He was moved to write a warning letter to the man in charge of the Osaka Office for his erratic reports of sales results. He also lamented, with some feeling, the seeming unconcern that the marketing staff at the Osaka Office were displaying, and whether it would be at all possible to get them to extend these activities sufficiently for the company to expand its market in so competitive an area. This was a rare outburst for Daigoro, on the whole an affable man by nature.

On May 19 he recognized the need for a specific product if Yasukawa Denki was to succeed in expanding its sales, and on June 14 he mentioned to Nunome the possibility of rationalizing the product line. On this occasion Nunome insisted on maintaining the existing position and Daigoro's ideas did not bring concrete results. Daigoro then proceeded to analyze sales figures for the period between August and September 1928. As a result of this he became ever more convinced for the need to concentrate production on specific products. On August 10, he wrote in his diary that if the firm maintained its existing ways of doing business, it would not be viable. Therefore if substantial improvement was to be achieved, the product range had to be limited to those items that were profitable or, alternatively, go all-out for a massive increase in production, more than $30 \%$, to be effective. He certainly perceived that there were two choices. By August 13 he recorded that the main thrust of future production should be focused on electric motors and that the production of unprofitable transformers and switchboards be gradually reduced.

Basing his judgment on the report from the accounting clerk, Daigoro for the first time clearly named the products relevant to the future strategy. On August 31, having taken into account the company data, he concluded that an immediate measure for improving company performance would be an increase in the production of motors for the spinning industry, which were profitable, while at the same time reducing the production of transformers. His ideas on rationalizing the product line, which had not been very clear when he discussed them with Nunome, had by now begun to take firm shape, although at this stage he was thinking not so much of a drastic change but a gradual phasing out of some of the less profitable lines. However, Daigoro kept these thoughts largely to himself and they were certainly not immediately reflected in company policy.

The marketing policy of the sales office was still heavily dependent 
on transformers and their accessories. There does not appear to have been any discussion between Daigoro and Nunome since June 1928 to coordinate and adjust their differing ideas on the company's future product policy. There was a definite lack of coordination between these two key men within Yasukawa Denki during 1928 and basically it was Nunome's decisions that were followed. However, by 1929 even Nunome had to admit the need for a reexamination of the product line. A 'Committee for the Determination of Product Items' was established in July 1929 , beginning a reappraisal of the product lines. The Committee, headed by Nunome, had eight members, including Taiichi, who was to lead the move toward product rationalization. This committee played an important part in preparing the company for the coming changes in its management policy.

\section{The Showa Crisis and Product Rationalization}

\section{(1) Decrease in Orders and Shift to Small Motor Production}

At the meeting of the Board of Directors held on December 9, 1929 , it was decided that the company's capital was to be reduced from $¥ 3 \mathrm{M}$ to $¥ 8 \mathrm{M}$. The money thus made available was to be used to write off losses brought forward, and to pay off existing debt. This was made possible by the cooperation of the Yasukawa member families who, as shareholders of the company, agreed to shoulder the burden. With the recent improvement in company operations, Yasukawa Denki stood on the threshold of a new beginning. At the board meeting on February 27, 1930, it was decided to increase capital to $¥ 3 \mathrm{M}$ once again to obtain the necessary working funds. However, from June of the same year, immediately after Daigoro's departure for Europe as the Japanese delegate to the Sekai Doryoku Kaigi (World Power Conference) in Berlin in May 1930, the effects of the Showa Crisis began to affect the industry, and Yasukawa Denki faced an extremely difficult situation.

Orders, which had averaged $¥ 170,000$ per month until May 1930 , began to decline from in the following month. The monthly average for all of 1931 did not exceed $¥ 94,000$. Moreover, these orders were accepted even when they meant average losses of slightly over $15.6 \%$. The number and the capacity of transformers the company produced dropped heavily, and the production of super-synchronous motors, which had been increasing up until then, almost ceased in 1931.

What is interesting, however, is that the number of induction 
motors produced continued to increase during the Crisis. This was a result of the success of the anticipatory production policy on small motors begun in 1928, which now drew stable orders. The sales volume of these small standard motors was 2,127 in 1931, and this increased to 3,273 in 1932, making standard electric motors the main product of Yasukawa Denki.

In 1930, a new distributor specializing in selling small motors to small customers in a wide variety of trades, mostly food processing, such as kamaboko (fish meat loaf) and tofu (bean curd) makers, was established. This distributor, who had been the sole agent of American electric motors in the Kansai Region and also had acted as a distributor for Hitachi until then, decided to sever all connection with them, and work for Yasukawa Denki alone. It is said that this came about when Taiichi, on seeing an advertisement for motors and pumps put out by the distributor, suggested to the marketing manager of the Osaka Office that he should approach the distributor to persuade him to handle motors made by Yasukawa Denki. This was apparently successful and it showed that a start had then been made on the systematic organization of distributors for standard electric motors which was to begin in earnest in 1932.

Even during the Crisis, the use of motors continued to widen. The sale of motors for machine tools was initiated by the production of the 25HP pole-change motor for Okuma Tekkosho (Okuma Manufacturing Ltd) in Nagoya, which ordered it for their new high-speed lathe. Taiichi was again behind this development, and the Chief Engineer of Okuma Tekkosho, who was keen on the electrification of machine tools, was persuaded to take up the idea of using the motor. This product incorporated a pushbutton control system, at that time an entirely new feature. Similarly the use of commutator motors for spinning machines was changed in favor of high-efficiency induction motors when the Hi-Draft spinning machine was introduced.

Yasukawa Denki recorded production of nearly 700 motors of this kind in 1931, an increase over the year before. But despite the increase in demand for small electric motors, the combination of a decrease in orders for large goods and falling prices caused a significant worsening of the operating results since the increase in the capital. Year-end results in 1931 showed losses of approximately $¥ 550,000$, almost half the total of orders received for the year. Clearly the Showa Financial Crisis forced Yasukawa Denki to consider that fundamental changes were needed to improve its management. 


\section{(2) Rationalization of Products and Organizational Reform}

The three main measures taken against worsening corporate performance during the Showa Crisis were the rationalization of products, rationalization of the workforce and industry-wide harmonization of products. By the board of directors' meeting of June 11, 1931, the losses the company had been absorbing had reached so serious a stage that a reference is found confirming that a proposal for product rationalization was discussed at the board level. It is usually understood that the majority opinion at that meeting recognized that there was no alternative but to reduce the number of products and concentrate production on electric motors if the company was to survive. However, it is more likely that at that particular point in time there still existed strong opposition to product rationalization, which would have prevented any decision being reached.

Later, in early October, Taiichi Yasukawa, who was then design manager, submitted a proposal for product rationalization. At the two subsequent board meetings held the same month, the rationalization plan was hammered out and decided. The plan contained decisions to eliminate transformers and items related to switchboards from the product range, and limit production to rotary machines, centered on electric motors and associated control devices. The staff and workers employed in the sections producing transformers and switchgear were also targeted for rationalization.

Daigoro had initially declined an invitation from Namihei Odaira, President of Hitachi, to join a cartel in June 1931. But as he was basically not against the formation of cartels, Yasukawa Denki joined four other heavy electrical manufacturers in a marketing agreement in March 1932.6

The actual task of reorganizing the product range took until the end of May 1932 to complete, as this also required wide-ranging organizational reform and a change in personnel policy. On February 26, 1932 Daigoro was visited by Toshitaka Horiuchi of the Meiji Mining Company, who, representing the views of related companies, recommended further personnel rationalization. Daigoro resisted this, offering several reasons, one being that he first wanted to see the results of the cartel agreement. In the end Daigoro's choice turned out to be the right one - the market recovered. However, this afforded only a temporary respite, and Daigoro was aware of the need to take positive measures to solve the problem. He convened a special meeting with Seizaburo, Taiichi and Gen'ichiro Hirayama of Meiji Mining Company, who made a joint decision to reform the manage- 
ment structure. Taiichi, a line manager close to those on the factory floor, was included in this important quorum; there was clearly an emerging environment for decision-making by top managers where the opinions of the line manager were valued.

The post of general manager was abolished as of May 1, 1932, and Nunome was retired temporarily. Nunome was not the only one who left because of the reorganization. Five long-serving members headed by Sales Chief Toru Obata also retired, leaving some upper management positions open to new talent.

In terms of organizational structure, the existing three-department system of Finance, Manufacturing and Sales was abolished, and in its place a simpler, two-department system consisting of Marketing \& Sales and Technical Divisions was established. Taiichi Yasukawa was appointed Technical director and Gen'ichiro Hirayama from Meiji Mining Co. was installed as director of Marketing and Sales.

Taiichi Yasukawa was the prime mover in product reorganization. Taiichi had been made Design Manager in the personnel reorganization of December 1930, and since then had begun rationalizing the product range with the concurrence of Nunome.

When he became Design Manager, his ideas for reducing the number of products available was interpreted as leading to an overall reduction in the operations of Yasukawa Denki. Resistance to the rationalization plan was too strong for it to be accepted. Nunome, who was active in the development of new products and the expansion of sales outlets and had ideas similar to Taiichi on this, nevertheless was not in favor of reducing the product range, probably due to his positive attitudes toward business. He was also rather reluctant to carry through an idea that he knew would generate resistance from long-serving company colleagues, and thus the policy was not implemented at that time.

But it struck a sympathetic chord in the thoughts of Daigoro, who had been taking careful note of the profitability of electric motors since 1928. This led to the decision at the October 1931 board meeting. Furthermore, when Taiichi stepped in to take the place of retiring Nunome as the new Technical Director, he stipulated that he must have total control of the product rationalization program. At last Taiichi, who was made responsible for production as a result of the reorganization, had the opportunity to practice what he had been preaching. 


\section{Economic Recovery \& Rapid Growth}

(1) A Sales Policy Switch and Expansion of Motor Applications In May 1932 the sales policy of Yasukawa Denki was changed to concentrate on electric motors, since the manufacturing system was already focused to that end. According to the recollections of Kakuzo Tanaka, then newly appointed as deputy director of Marketing and Sales and posted to the Tokyo Office at the end of 1931, the firm was making a fair number of other products, such as induction voltage regulators. At that time the Tokyo Office was apparently still handling the orders for these products. But orders were no longer accepted for these items once product rationalization got underway. The rationalization program progressed even more smoothly in conjunction with the cartel agreement which began operating at the same time. Yasukawa Denki was able to fairly easily change its product structure within the limits of order ratios set by the cartel agreement.

Moreover the switch in sales policy did not lead to a reduction in sales items, but rather involved an expansion of the company-owned sales network and the distributor network for promoting sales of electric motors. The upgrading of the Osaka Sales Office to a Marketing \& Sales Office, the establishment of a Sales Office in Nagoya where there had only been a temporary office since 1930 , the stationing of permanent staff in Taipei, and the opening of a Tokyo Sales Office, which would handle the cartel agreement, all took place in 1932. Two years later, this was followed by the stationing in the Tokyo Sales Office of a permanent staff member to look after sales in the Hokkaido region. An examination of sales distribution figures by region shows that in 1931, a very high $61 \%$ of sales was handled by the Head Office, followed by Osaka with $30.8 \%$. However, by 1935 the rate for the Head Office fell to $34.6 \%$, whereas that for Osaka rose to $34 \%$. The new branch office in Nagoya handled $6.5 \%$, and sales through the Tokyo Office rose rapidly, from $7.8 \%$ in 1930 to $24.7 \%$ by 1935 . Yasukawa Denki's presence in the market north of the Kanto Region, including Hokkaido, was now well established and its sales outlets spread nationwide.

Since 1932, when the policy to expand the distributor network was made, many distributors had been added in the Kansai Region. The existing distributors that had been handling sales of electrical power machinery and equipment were now switched to specialize in electric motors. In the case of Tokyo, owing to Yasukawa's late entry into the market, only one distributor existed in 1932. Sales of electric motors 
were about five motors per month. Toshio Sato, who was posted to the Tokyo Sales Office in May 1932, recalls that on his appointment he was given a brief to put his efforts into the sale of standard electric motors, and he took on the task of increasing the number of distributors: by 1936 the Tokyo Office was selling over 100 motors every month.

With the change in marketing policy, the yearly total sales of Yasukawa Denki began to show a marked increase from 1932, and the company showed its first profit at the end of that year. Although this was reported as less than $¥ 7,000$, if the losses from previous years are excluded, profit for 1932 alone amounted to $¥ 200,000$. A breakdown of completed products shows that small AC electric motors held the biggest share by far. Moreover, standard motors, which had accounted for $25.9 \%$ in 1932 , increased to $30 \%$ in 1936 . This reflected a situation where the mass-production system for standardized products was becoming well established. Yasukawa Denki achieved rapid growth as a specialist manufacturer of electric motors after the rationalization of its product line.

One characteristic of the 1930s was the rapid expansion of applications and scale of production for electric motors that had been developed from the late 1920s to the period of the Showa Financial Crisis. The main customers for heavy electrical machines were the electrical power industry and railways. However, the orders Yasukawa Denki received in 1932 came largely from government and public agencies and the iron \& steel, ceramics, machinery, cotton spinning and processing, mineral extraction and shipbuilding industries. This was clear indication that Yasukawa Denki's success was built on growing demand for electric motors as industry electrified.

Although the production of high-efficiency induction motors for the spinning industry decreased temporarily in 1932, the situation was reversed in 1933 and the following year it increased fourfold, approaching 4,000 motors. The demand for motors for machine tools increased rapidly from 1933 with the trend toward equipping each machine tool with its own motor. The number of motors supplied for 1936 was four times that for the previous year. At the same time the areas where synchronous motors and super-synchronous motors were applied expanded, and large motors were supplied to the iron \& steel, coal-mining and cement industries. In the process of recovery from the effects of the Showa Crisis, Yasukawa Denki added to its lists new customers in heavy industries such as iron \& steel and machinery. This opened fresh markets for electric motors and the 
application of control devices. Profit on total sales in 1936 for supersynchronous motors was $52 \%$, with synchronous motors at $33 \%$. But small standard motors were relatively low, $15 \%$ through distributors and $24 \%$ by direct sales, indicating the important role that the increased sales of highly profitable, large models played in the improvement of Yasukawa Denki's performance.

\section{(2) Decision on Capital Investment}

It was necessary to greatly expand the existing plant to realize Taiichi's ideas for an ideal factory specializing in electric motor production. This started the process of drawing up an expansion plan in April 1933, when the improvement in performance began to show. However, there was considerable opposition to this plan within the company, and Taiichi's original expansion plan had to be modified. The first stage in Taiichi's plan was to remove 1,500 tsubo (1 tsubo 4 sq.yds.) of wooden structure from the existing 3,000 tsubo factory building to be used for welfare or warehousing purposes. There was also the construction of a new, 3,000 tsubo building, which would have allowed extension of the main factory to establish a new Number Three Rotary Machine Workshop to specialize in the production of small electric motors, expansion of the foundry and other workshop facilities.

Daigoro supported this plan completely, and it is said that President Seizaburo also gave his 'consent in general.' The plan was then submitted to the board of directors' meeting in October 1933, and the decision to approve it was made when Auditor Kenjiro Matsumoto declared to all present that the matter of rebuilding the factory was an established policy. However, strong opposition arose later from some of the directors, who demanded that implementation of the rebuilding plan cease, creating a situation where the plan agreed to by both Seizaburo and Kenjiro and passed by the board had to be withdrawn. This kind of situation had never occurred before. After this, Seizaburo advocated 'economies,' and Gen'ichiro Hirayama, director of Marketing and Sales, advocated 'negativity and prudence.' This was evidence of the formidable obstacles to the expansion plan.

Daigoro, who worked hard to find a compromise between the opposing groups, suggested a limited plan involving only the extension of the existing main factory building (Number One Rotary Machine Workshop) to Taiichi, but Taiichi insisted that the extension of the main factory building, the building of the Number Three Rotary Machine Workshop for producing small motors and the warehouse 
for completed products were the absolute minimum. In the end, Taiichi's position was basically accepted, a compromise was reached by postponing the expansion of the foundry and welding workshop to the following year, the expansion plan was approved at the November board meeting and remodeling work began.

Taiichi also had plans for the second and third stages, and managed to persuade those directors who had been opposed to his original plan to come around to his way to thinking. Work on the second stage of the expansion began in August 1935 with the building of foundry and welding workshops postponed earlier. By this time, Daigoro had changed his view in favor of positive action, to the extent that his opinions clashed with those of Seizaburo, who was still inclined toward prudence. For example, the differences between them were shown clearly in February 1936 over the building of new offices. Seizaburo was against it because he thought that it would not be appropriate to expand only Yasukawa Denki and not other related family firms. Daigoro's rebuttal was that the company would be left behind by their competitors if it remained negative. It is said that this was the first occasion when there was a real difference of opinion between them. While Daigoro, representing an expanding Yasukawa Denki, had somewhat uncharacteristically stuck to his position supporting the expansion, Seizaburo, coordinating all Yasukawa enterprises, had to be cautious about the speed with which Yasukawa Denki was growing.

The very next day, Seizaburo died suddenly. Daigoro was made president on February 26. The following month, Taiichi was appointed a director.

Under the leadership of President Daigoro, Taiichi suggested the construction of a new Number Two Rotary Machine Workshop for exclusive production of medium-sized electric motors as the third stage of the expansion plan. This was approved, without much opposition, at the board of directors' meeting of July 2, 1936. Taiichi further envisioned a transfer of the production of control devices from the Number Three Rotary Machine Workshop - where it occupied half the building - to a new facility built specially for it as the fourth stage of the expansion plan, and he intended to start on construction right away. However, this idea met with strong opposition from Daigoro, who had until then been sympathetic to Taiichi's views. Taiichi recalled wryly that on this occasion Daigoro was not very pleased with him and gave him a telling-off. Nevertheless, Taiichi stuck to his guns, and Daigoro eventually relented, giving Taiichi 
permission to start work on the building.

Taiichi was the driving force behind this expansion, spread over four stages and several years. He believed strongly in mass production allied with rationalization. In May 1938, when the plan was completed, he was made managing director, and with Daigoro as president formed the top management of Yasukawa Denki. Daigoro had initially been receptive to Taiichi's ideas for expansion and gave support to their realization. However, once he assumed the position of responsibility as president on Seizaburo's death, he began to take a more cautious position, as Seizaburo had done. He was no longer free to consider only the future of Yasukawa Denki itself, but now had to give priority to the well-being of the Yasukawa family business as a whole. The constraints on the expansion of Yasukawa Denki arose from the difficulties resulting from the necessity to adjust conflicting interests involving the companies of the Yasukawa extended family.

\section{Conclusion}

The genesis of Yasukawa Denki owed much to the entrepreneurial spirit of Keiichiro and the support and cooperation given by the extended family. The role the Yasukawa group firms played in helping consolidate the manufacturing and marketing organizational base was also considerable. However, the lack of a clear policy in the development of the manufacturing and marketing organizations placed Yasukawa Denki in a weak position, unable to capitalize on the opportunities offered by the First World War and the Great Kanto Earthquake, and it continued to perform poorly. After the mid-1920s Yasukawa Denki began to successfully develop new and individualistic products, centering on electric motors. This was made possible by the formation of a layer of engineers within the company who had the ability and imagination to develop new products, and the successful product rationalization in 1932 was built on this foundation. After that, a further effort was made to open up new fields of application for motors and control devices while the marketing and sales organization was restructured, enabling the company to capture the growing electric motor market.

The growth of Yasukawa Denki and the parallel strengthening of the position of the salaried managers represented by Taiichi created a problem in adjusting the conflicting interests between Yasukawa Denki and other firms in the Yasukawa Group. Under the leadership of Keiichiro in the early stages and, after his retirement, under Kenjiro 
and Seizaburo, problems were solved quickly in a climate of family solidarity. However, from the time of the Showa Financial Crisis and during the period of recovery after it, the Yasukawa diversified family business had to face the difficult problem of dealing with the conflicting interests of its group members. The salaried managers were as yet not in position to regulate their conflicting individual interests within the broader perspective of the whole Yasukawa family business, and the members of the Yasukawa family were burdened with the difficult task of dealing with the problem themselves. As a diversified business enterprise, the Yasukawa family business was at the stage where it needed systematic regulation of the interests of its group members, but it never quite managed to acquire the necessary organization and salaried managers capable of dealing with the problem before the end of the decade. ${ }^{7}$ As a result, it would be correct to regard the Yasukawa family business between the wars as a business engaged in the process of growing into a zaibatsu, but which still lacked the substance required of a diversified enterprise.

\section{Notes}

1. On the various conditions under which Yasukawa Denki operated between the wars, see: Shin Hasegawa, "Senkanki no JudenkiKogyo ni okeru Senmon-Maker no Hatten" ("The Specialization of the Japanese Electrical Equipment Manufacturers in the InterWar Period), "Shizuoka Daigaku Kyoikugakubu Kenkyuhokoku" Jinbun Shakaikagaku-hen Dai 33 go ("Bulletin of the Faculty of Education, Liberal Arts and Social Sciences," Series 33), Shizuoka University, 1982, pp. 27-41.

2. Hidemasa Morikawa, "Chiho Zaibatsu" ("Regional Zaibatsu"), in Nihon no Zaibatsu, ("The Japanese Zaibatsu"), Nihon Keieishi-Koza 3 (Vol. 3, Japanese Business History), Nihon Keizai Shinbun-sha, 1976. Chiho Zaibatsu ("Regional Zaibatsu") by Hidemasa Morikawa, Nihon Keizai Shinbun-sha, 1985.

3. Bibliography

Yasukawa Denki 40-Nen-shi ("40-Year History of Yasukawa Electric Co."), by Yasukawa Denki 40-Nen-shi Henshu Iinkai (Committee for Compilation of the 40-Year History of Yasukawa Electric Company), Yasukawa Denki Seisakusho, 1956.

Yasukawa Daigoro Den ("Biography of Daigoro Yasukawa") by Yasukawa Daigoro Den Kankokai (Publishing Committee), 1977. Yasukawa Daigoro Iko to Tsuiso ("Papers of Yasukawa Daigoro 
Published Posthumously, and Recollections by Him") by Yasukawa Daigoro Den Kankokai, 1977.

Yasukawa Keiichiro Nikki ("Diary of Keiichiro Yasukawa").

Gijitsusha no Techo ("Notebooks of an Engineer"), by Taiichi Yasukawa, 1955.

Yasukawa Denki Seisakusho Shozo Shiryo ("Historical Materials of Yasukawa Electric Co.").

4. It is said that Taiichi Yasukawa was born to the daughter of the eldest brother of Keiichiro Yasukawa and Keiichiro's adopted son, an outstanding member of the sales staff in YasukawaMatsumoto Trading Co. who so impressed Keiichiro that he decided to bring the young man into the family by adopting him. Taiichi worked for Ajikawa Tekkosho (Ajikawa Manufacturing Co.) after his graduation in 1917 from Meiji Senmon Gakko (Meiji Technical College), where he specialized in Mechanical Engineering. He had always held to the idea of standardization and specialization in products, and he resigned from Ajikawa Tekkosho after a suggestion he made along this line to the Chief Engineer was rejected. He was then employed by a muslin manufacturer in Tokyo until he entered Yasukawa Denki in 1926. His position within the Yasukawa extended family was low, and his job experience and the circumstances for his hiring such that no promise was made for his eventual promotion to top management at the beginning of his career in Yasukawa Denki. In this paper, he is therefore regarded as a salaried manager in top management of the company, even though he is a member of the Yasukawa family.

5. S. Nunome, born in 1878, entered Yawata Seitetsujo (Yawata Ironworks) on graduation from the Department of Mechanical Engineering, Kyoto Teikoku Daigaku (Kyoto Imperial University). After some years working for Minami Manshu Tetsudo (South Manchuria Railway Co.), he became a consultant to Kyushu Seiko (Kyushu Steel Works) in 1921. At the time he entered Yasukawa Denki as director of manufacturing, he also operated as works manager, and in 1928 took on further responsibility as purchasing manager. The following year he was appointed director with a seat on the board, at the same time acting as general manager and director of Marketing \& Sales, thus shouldering responsibilities covering both the manufacturing and sales sides of the business.

6. "Judenki Cartel (Satsukikai)" (Heavy Electric Machine Cartel) by S. Hasegawa in Ryotaisenkanki Nihon no Cartel (Japan's Cartels in the Inter-War Period) by Juro Hashimoto \& Haruhito Takeda 
(ed.), Ochanomizu Shobo, 1985, pp. 273-322.

7. Yasukawa Matsumoto Gomeigaisha (Yasukawa Matsumoto \& Co.), a limited company established in 1935 , was created mainly to safeguard the family fortune, and had no controlling power as a parent company.

Translated by Isako Ward Okazaki 